\title{
AN INVESTIGATION OF PATTERN MAKING OF TWISTED DRAPERIES
}

\author{
Zlatina Kazlacheva, Petya Dineva \\ Faculty of Technics and Technologies of Yambol, \\ Trakia University of Stara Zagora, Bulgaria \\ Graf Ignatiev 38, 8600 Yambol, Bulgaria \\ e-mail: zlatinka.kazlacheva@trakia-uni.bg, petya.dineva@trakia-uni.bg
}

\begin{abstract}
One of the ways of design of draperies in clothing is by twisting of a piece. Usually patterns of that type of draperies are a result of moulage or draping method. A study of pattern making systems shows only one way for constructing of twisted draperies, which area result of transformation of bust darts. But this type of draperies can be situated in different areas of the clothing, not only in the bust area. Therefore it could be developed a systematic way for pattern making of twisted draperies without transformation of darts. Development of a system of pattern making of twisted draperies without transformation of darts is the aim of the paper. After the twisting, the draperied piece changed its sizes. Its width and height become smaller. If dependences between sizes of pieces before and after twisting will be found, the methodology of pattern making of twisted draperies would be full systematized. On the base of the measurements two linear regressions are realized for determination of the shortening by the width and height. The measures of the width and height shortening have to be added to the width and height of the pieces, which will be twisted. With the help of dependences for calculating of the additional width and height of the draped piece, which are results of presented regression analysis a system of pattern making of twisted draperies is developed. The developed system gives possibility for easy and correct pattern making of twisted draperies. The system facilitates the process of fashion design and pattern making especially on ready-to-wear industry and gives opportunity for variety of models with twisted draperies.
\end{abstract}

Keywords: fashion design, pattern making, drapery, twisted draperies, linear regression.

\section{INTRODUCTION}

One of the ways of design of draperies in clothing is by twisting of a piece. Usually patterns of that type of draperies are a result of moulage or draping method. A study of pattern making systems shows only one way for constructing of twisted draperies [1], which area result of transformation of bust darts. But this type of draperies can be situated in different areas of the clothing, not only in the bust area. Figure 1 presents two models of ladies dresses with twisted draperies in the waist and in the bust. Therefore it could be developed a systematic way for pattern making of twisted draperies without transformation of darts.

Development of a system of pattern making of twisted draperies without transformation of darts is the aim of the paper.

\section{METHODOLOGY}

After the twisting, the draperied piece changed its sizes. Its width and height become smaller. If dependences between sizes of pieces before and after twisting will be found, the methodology of pattern making of twisted draperies would be full systematized. The dependences will be searched with the help of two-variable linear regressions. [2] 


\section{ARTITE}
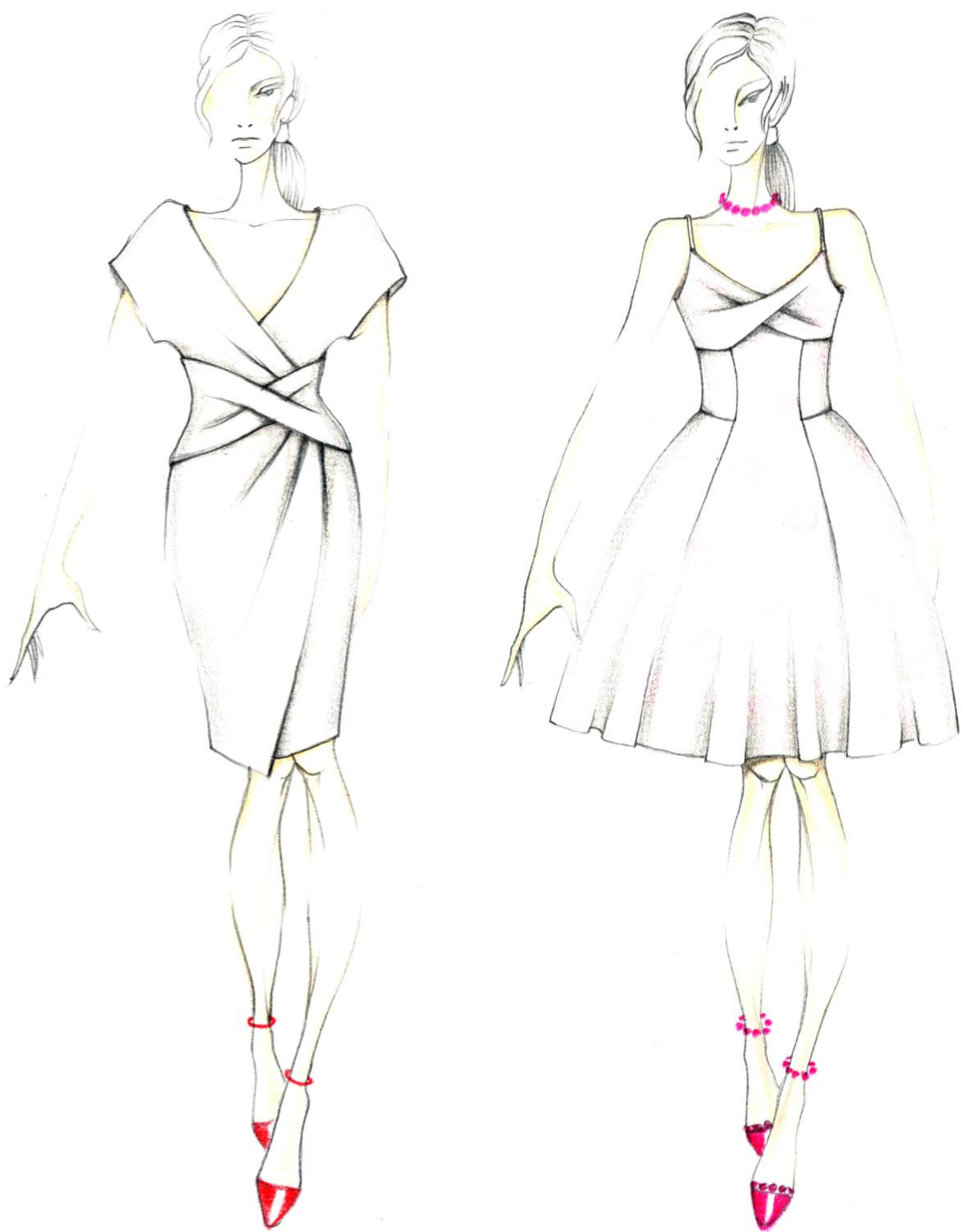

Figure 1. Ladies' dresses with twisted draperies in the waist and in the bust

IRTIIE Vol. 5, No. 2, 2017 ISSN 1314-8788 (print), ISSN 1314-8796 (online), doi: 10.15547/artte.2017.02.002 


\section{IRTTL $Y$}

Ipplied Reserertches in Technics, Technologies and Bduration

Journal of the Faculty of Technics and Technologies, Trakia University https://sites.google.com/a/trakia-uni.bg/artte/

Mathematical dependences are searched for the full systemized methodology of pattern making of twisted draperies. The problem is solved with the help of linear regression formula (1):

$$
Y=a+b_{1} \cdot X_{1}+b_{2} \cdot X_{2}
$$

where $\mathrm{Y}$ is the dependent variable; $\mathrm{X}_{1}$ and $\mathrm{X}_{2}$ - independent variables; $\mathrm{a}$ - constant; $\mathrm{b}_{1}$ and $\mathrm{b}_{2}$ - coefficients of regressions.

The systemized mythology has to be suitable for different fabrics with good drapability. By this reason three fabrics with good drapability but in different structures are chosen. From the three fabrics rectangles in skew direction are cut in the sizes by width and height: $40,0 \times 30,0$ $\mathrm{cm}, 40,0 \times 25,0 \mathrm{~cm}, 40,0 \times 20,0 \mathrm{~cm}, 40,0 \times 15,0 \mathrm{~cm}, 35,0 \times 20,0 \mathrm{~cm}, 35,0 \times 15,0 \mathrm{~cm}, 30,0 \times$ $20,0 \mathrm{~cm}, 30,0 \times 15,0 \mathrm{~cm}$. All pieces are twisted in the way, presented in Figures 2 without additional effort as result of the skew direction and gravity.

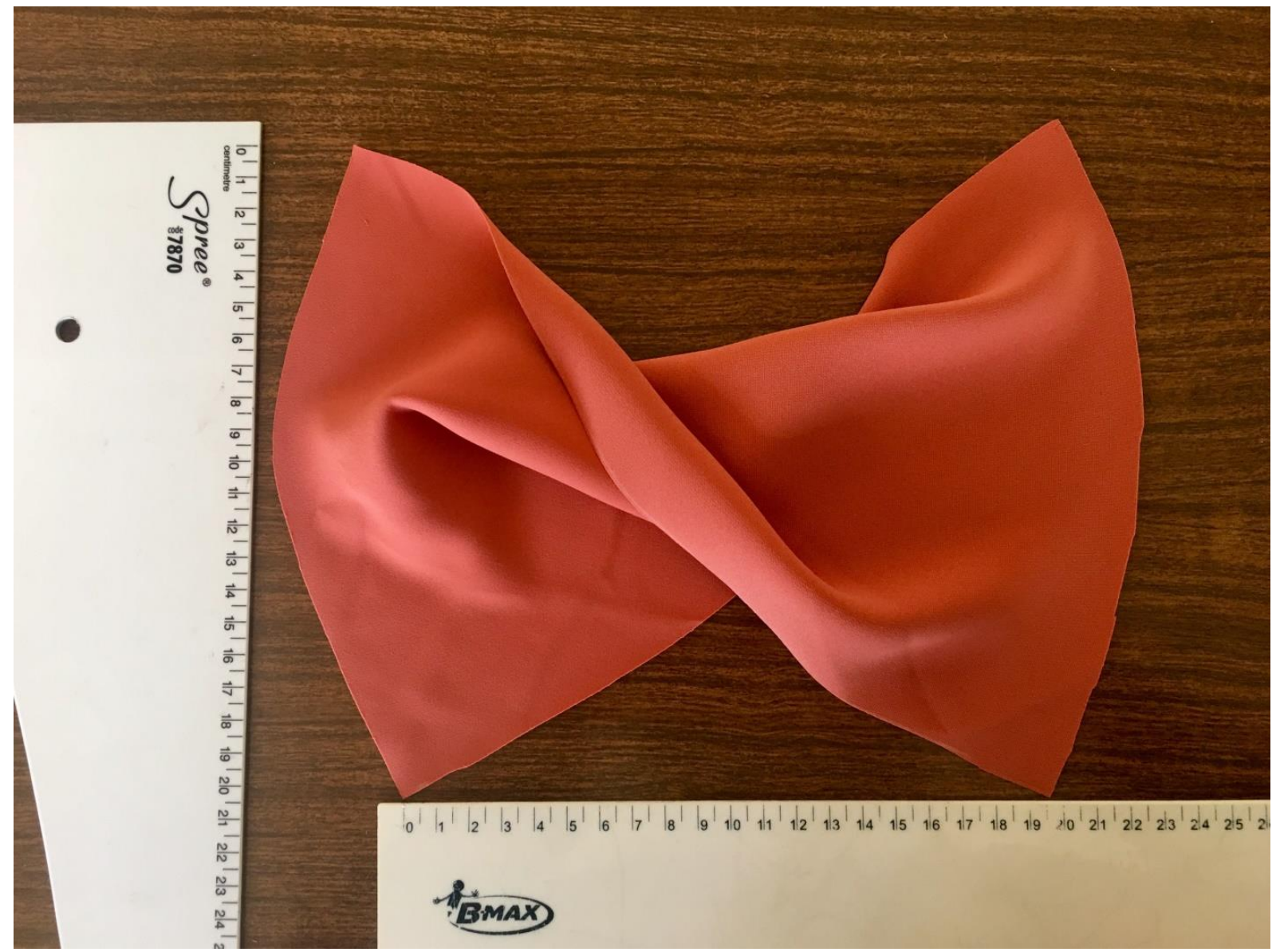

Figure 2. Measurement of the width and height after twisting

After the twisting the pieces are shortened in width and height directions. For every rectangle three time the shortened width and height are measured.

On the base of the measurements two linear regressions are realized for determination of the shortening by the width and height. The measures of the width and height shortening have to be added to the width and height of the pieces, which will be twisted. 


\section{IRTTE \\ Ipplied Researrothes in Technics, Technologies and Bductition \\ Journal of the Faculty of Technics and Technologies, Trakia University https://sites.google.com/a/trakia-uni.bg/artte/}

\section{EXPERIMENTAL}

For the determination of the additional width of the twisted piece formula (1) acquires mode (2):

$$
\text { Wadd }=a+b_{1} \cdot W p+b_{2} . H p
$$

where Wadd is additional width; Wp - primary width of the piece; $\mathrm{Hp}$ - primary height of the piece; $a$ - constant; $b_{1}$ and $b_{2}$ - coefficients of regression.

For the determination of the additional height of the twisted piece formula (1) acquires mode (3):

$$
\text { Hadd }=c+d_{1} \cdot W p+d_{2} \cdot H p,
$$

where Hadd is additional height; $\mathrm{Wp}$ - primary width of the piece; $\mathrm{Hp}$ - primary height of the piece; $c$ - constant; $d_{1}$ and $d_{2}$ - coefficients of regression.

The regressions are made with the help of the software STATISTICA 7.0. [3]

\section{RESULTS}

\subsection{Additional width - Wadd}

The linear regression results are $a=-3,14722, b_{1}=-0,03667, b_{2}=0,5144$. The accuracy of the regression model is provided by the values of $p<0,0000$, R-square $=0,90227262$, and Std. Error of estimate $=0,84287$..On the base of the statistical analysis formula (2) assumes form (4):

$$
\text { Wadd }=-3,15-0,037 . W p+0,5 . H p
$$

The linear interaction between dependent and independent variables is shown in Figure 3.

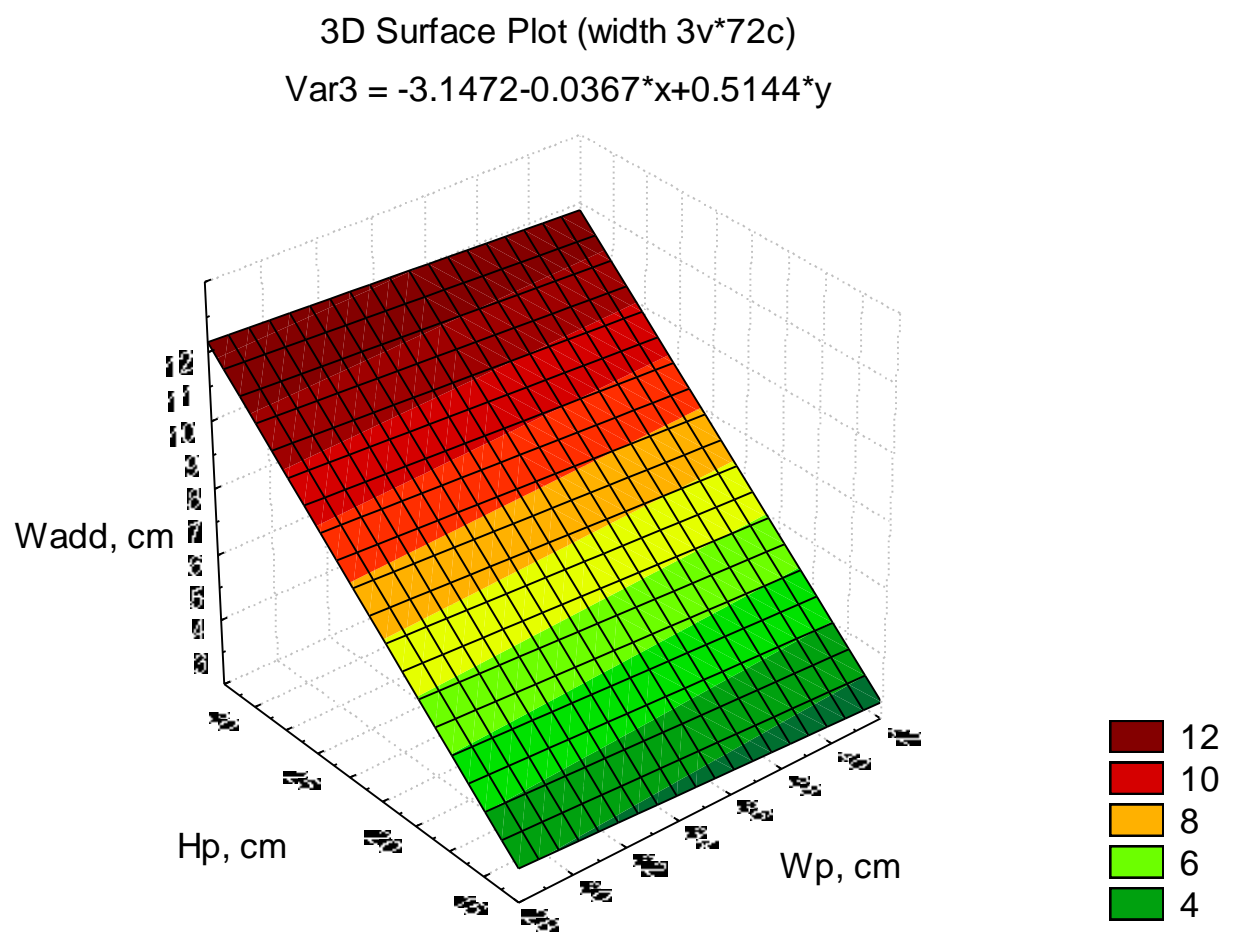

Figure 3. Linear interaction between dependent and independent variables IRTIIE Vol. 5, No. 2, 2017 ISSN 1314-8788 (print), ISSN 1314-8796 (online), doi: 10.15547/artte.2017.02.002 


\section{IRTIIE}

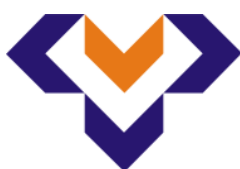

Ipplied Resseirl'hes in Teednicis, Technologies and Bductition Journal of the Faculty of Technics and Technologies, Trakia University https:///ites.google.com/a/trakia-uni.bg/artte/

After the two-variable regression analysis it is seen that the value of $b_{1}=-0,03667$ is minor and therefore an dependence between the dependent variable Wadd and the independent variable Hp without Wp can be searched. And formula (2) is transformed in (5):

$$
\text { Wadd }=a+b . H p
$$

After the regression analysis the results are: $a=-4,20139$, and $b=0,50069$. The accuracy of the regression model is provided by the values of $p<0,0000$, $R$-square $=0,899634$, and Std. Error of estimate $=0,84805$. After the regression analysis formula (5) assumes form (6):

$$
\text { Wadd }=-4,2+0,5 . H p
$$

\subsection{Additional height - Hadd}

The linear regression results are $c=-2,63671, d_{1}=-0,03667, d_{2}=0,5144$. The accuracy of the regression model is provided by the values of $p<0,0000$, R-square $=0,90227262$, and Std. Error of estimate $=0,84287$..On the base of the statistical analysis formula (3) assumes form (7):

$$
\text { Hadd }=-2,6-0,037 . W p+0,5 . H p
$$

The linear interaction between dependent and independent variables is shown in Figure 4.

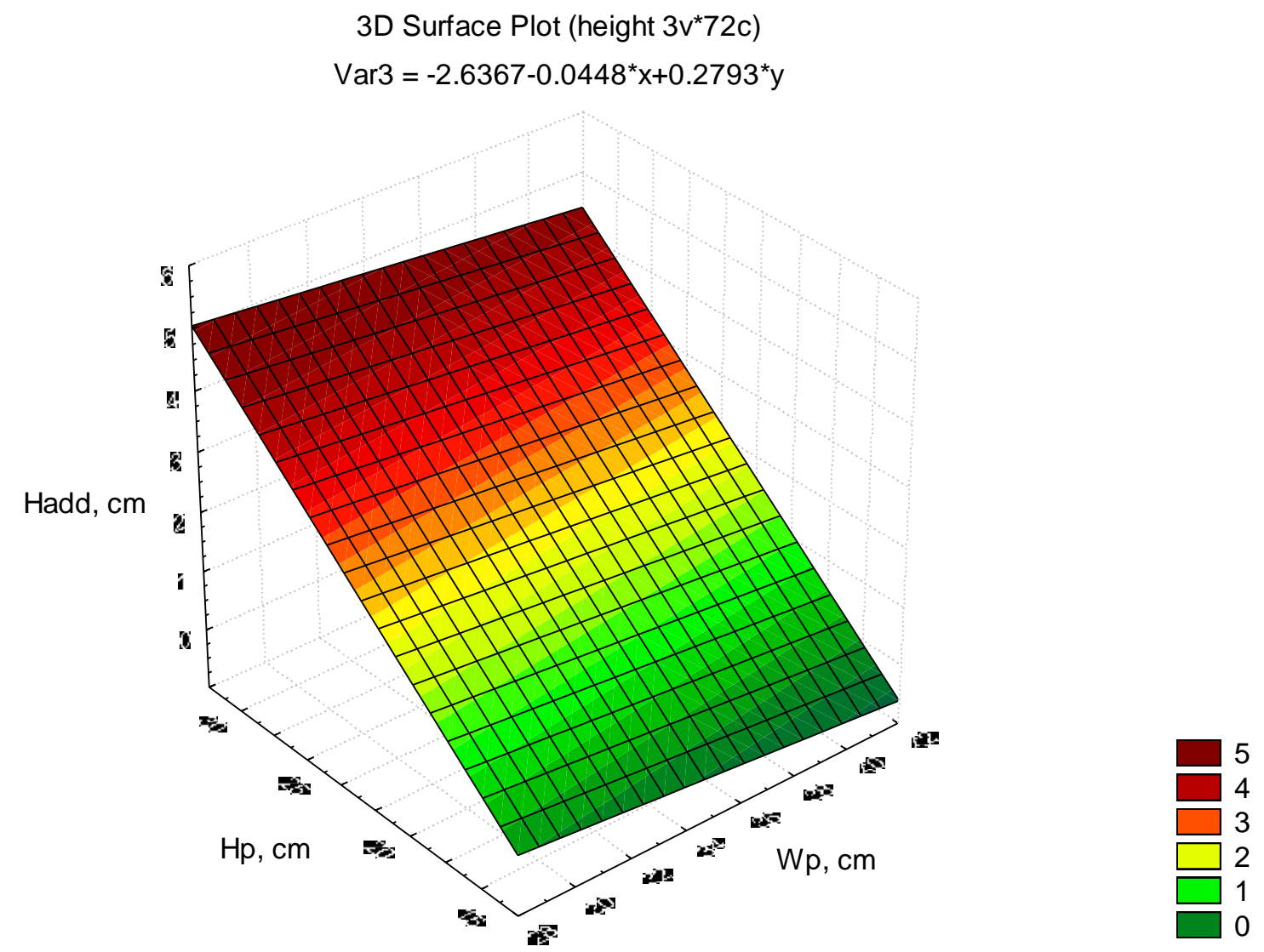

Figure 4. Linear interaction between dependent and independent variables

IRTIIE Vol. 5, No. 2, 2017 ISSN 1314-8788 (print), ISSN 1314-8796 (online), doi: 10.15547/artte.2017.02.002 


\section{ARTTIE}

Ipplied Researrothes in Technics, Technologies and Bductition

Journal of the Faculty of Technics and Technologies, Trakia University https:///ites.google.com/a/trakia-uni.bg/artte/

After the two-variable regression analysis it is seen that the value of $d_{1}=-0,03667$ is minor and therefore an dependence between the dependent variable Hadd and the independent variable $\mathrm{Hp}$ without Wp can be searched. And formula (3) is transformed in (8):

$$
\text { Hadd }=c+d . H p
$$

After the regression analysis the results are: $c=-3,92361$, and $d=0,26250$. The accuracy of the regression model is provided by the values of $p<0,0000$, R-square $=0,89680388$, and Std. Error of estimate $=0,44799$. After the regression analysis formula (8) assumes form (9):

$$
\text { Hadd }=-3,9+0,26 . H p
$$

\section{DEVELOPMENT OF A PATTERN MAKIG SYSTEM}

The system of pattern making of twisted draperies is presented with a design of a lady's blouse with a piece with twisted draperies in the neck opening. The same pattern making system can be used for different location of the draped piece in different types of clothing. The pattern making of the draped detail is presented in Figures 5 and 6.

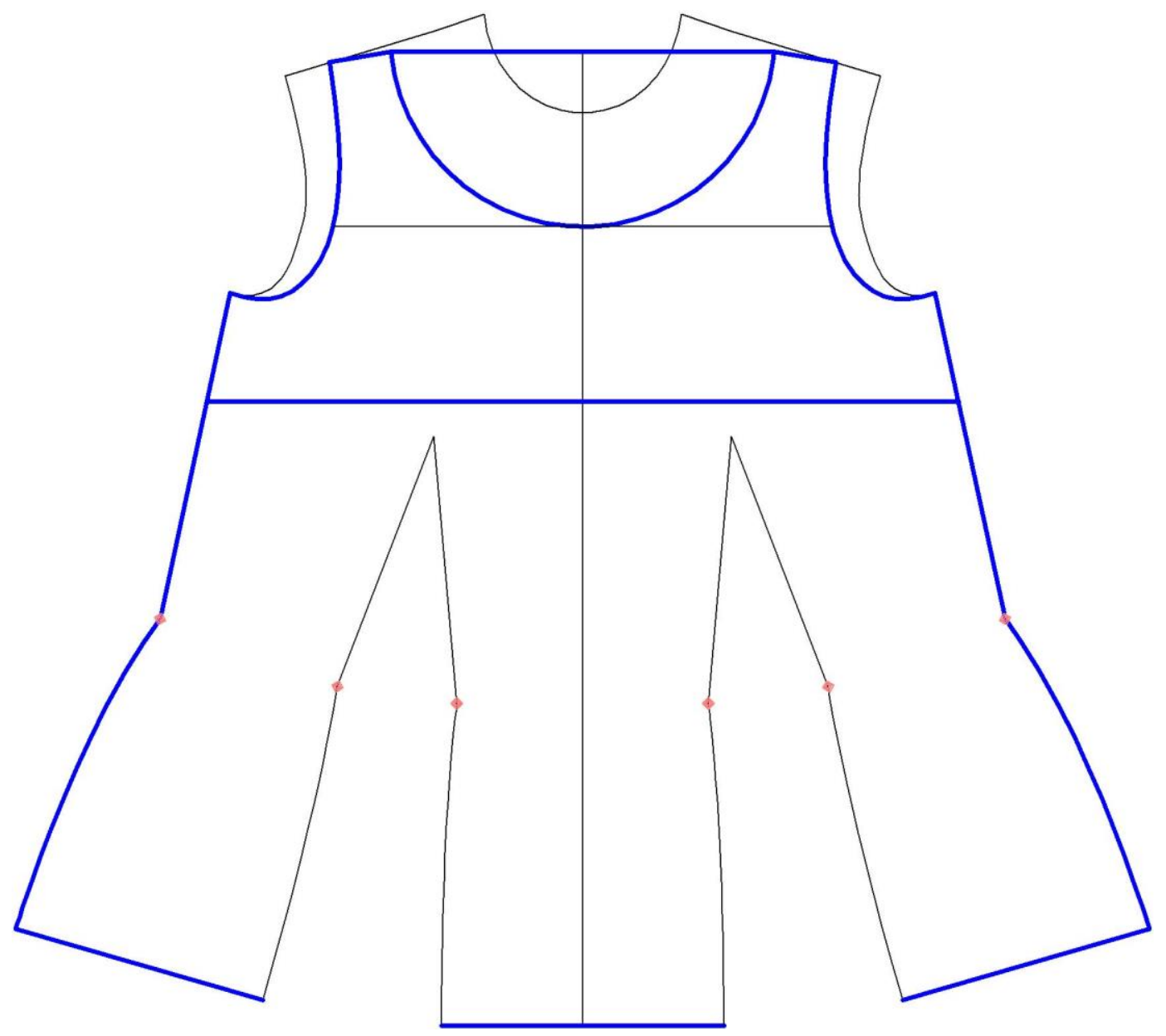

Figure 5. Pattern making of the twisted piece

IRTIIE Vol. 5, No. 2, 2017 ISSN 1314-8788 (print), ISSN 1314-8796 (online), doi: 10.15547/artte.2017.02.002 

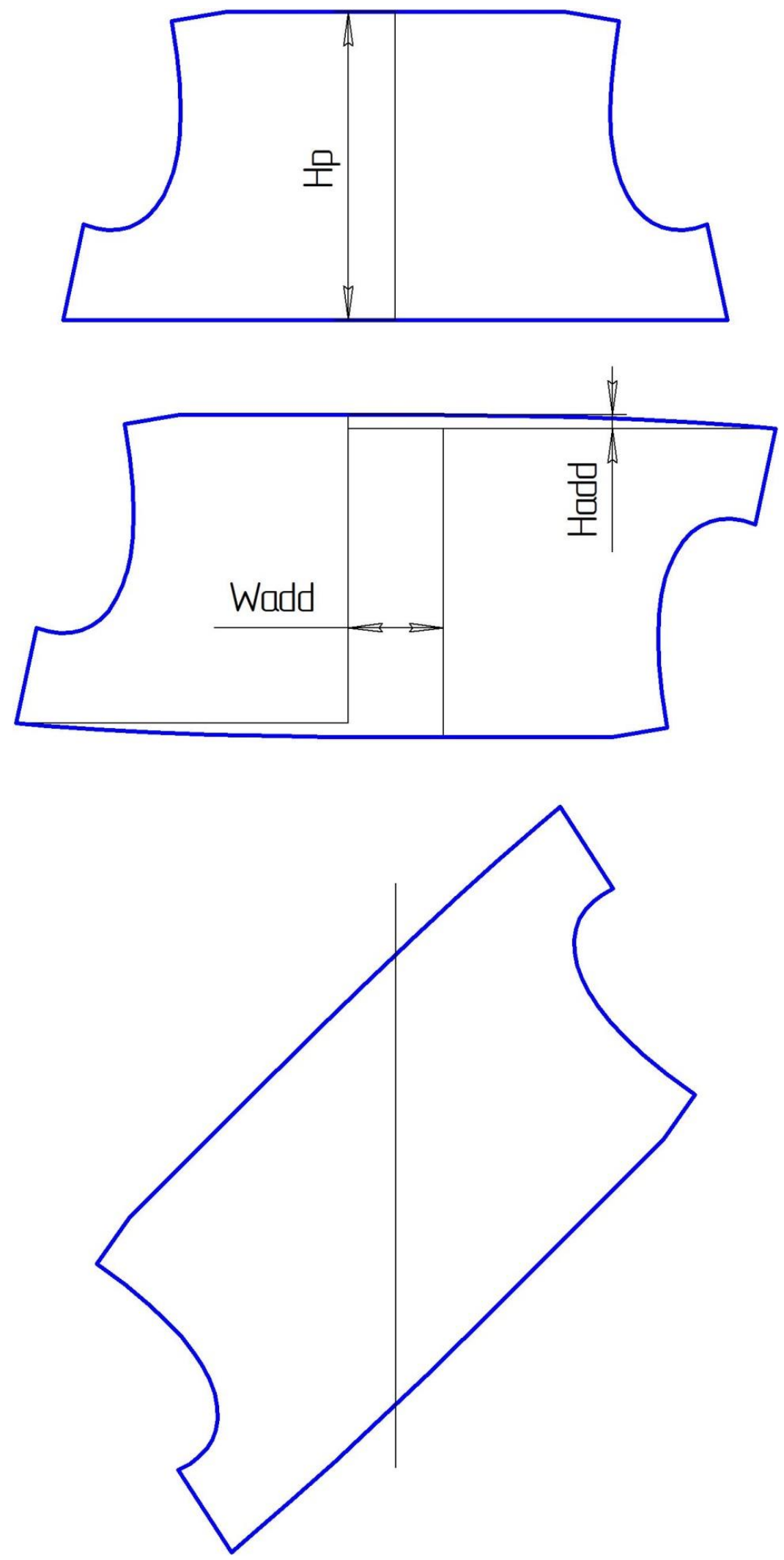

Figure 6. Pattern making of the twisted piece

IRTIIE Vol. 5, No. 2, 2017 ISSN 1314-8788 (print), ISSN 1314-8796 (online), doi: 10.15547/artte.2017.02.002 


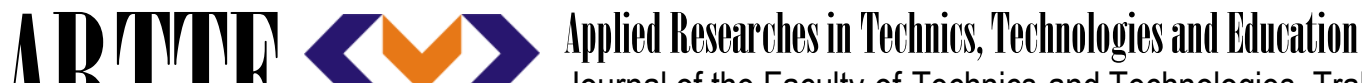 Journal of the Faculty of Technics and Technologies, Trakia University https://sites.google.com/a/trakia-uni.bg/artte/}

In Figure 5 the twisted piece is dawn on the front with two horizontal lines. A first line is situated between the points of intersection of shoulders and neckline. The second horizontal one is located between the contours of the side seams over the bust points. The piece is situated between the both horizontal lines, shoulders, arms holes, and the parts of the side seams contours which are located over the down horizontal line, The neckline of the front is formed with arc of a circle or with a similar curved line with depth to the middle of the height of the draped piece.

In Figure 6 the draped piece is divided in two halves into the middle vertical line. In horizontal direction the both halves are set on distance, which is equal to the additional width Wadd, calculated by formula (6) as the one of the halves is turned in its mirror image. In vertical direction the both halves are set on distance, which is equal to the additional height Hadd, calculated by formula (9). Than the both halves are connected with light curved lines and the piece is turned into 45 degrees for the skew direction cutting.

An experienced model is presented in Figure 7.

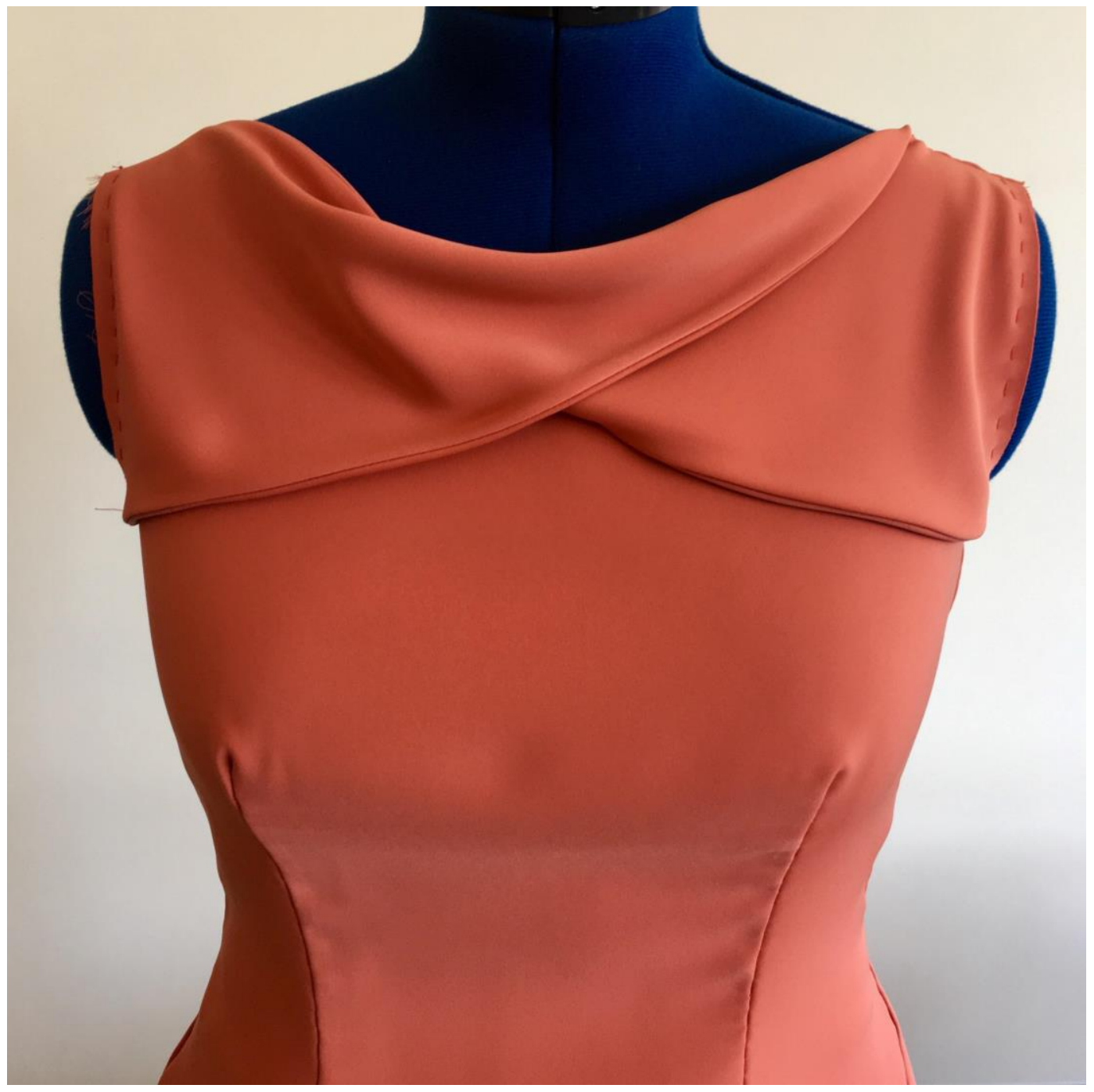

Figure 7. An experienced model with twisted draperies 


\section{IPITIP Journal of the Faculty of Technics and Technologies, Trakia University https://sites.google.com/a/trakia-uni.bg/artte/}

\section{CONCLUSION}

- With the help of dependences for calculating of the additional width and height of the draped piece, which are results of presented regression analysis a system of pattern making of twisted draperies is developed.

- The developed system gives possibility for easy and correct pattern making of twisted draperies.

- The system facilitates the process of fashion design and pattern making especially on ready-to-wear industry and gives opportunity for variety of models with twisted draperies.

\section{ACKNOWLEDGEMENTS}

The work is supported by the scientific project 2.FTT/ 2016 'Investigation of the Fashion Design and Pattern making of 3D Elements in Ladies' Clothing' funded by the Faculty of Technics and Technologies of Yambol, Trakia University of Stara Zagora, and the Fund of the National budget for scientific research in higher education in Bulgaria.

\section{REFERENCES}

[1] Nakamichi T. (2011). Pattern Magic 2. Laurence King, London, UK, 2010, ISBN 9781856697064.

[2] Kazlacheva Z. (2010). The Use of Suitable Methods of Statistical Analysis in Fashion Design and Clothing Constructing. Proceedings of the International Scientific Conference eRA-5, Piraeus, Greece, 15-18 September, 2010, pp. 432-437.

[3] Hill, T. \& Lewicki, P. (2007). Electronic Statistics Textbook. Available: http://statsoft.com/textbook/stathome.html [2007-2017]. 